\title{
Murid herpesvirus 4 (MuHV-4, prototype strain MHV-68) as an important model in global research of human oncogenic gammaherpesviruses
}

\author{
J. MISTRÍKOVÁ ${ }^{1,2}$, K. BRIESTENSKÁ2
}

\begin{abstract}
${ }^{1}$ Department of Microbiology and Virology, Faculty of Natural Sciences, Comenius University in Bratislava, Ilkovičova 6, 84215 Bratislava, Slovak Republic; ${ }^{2}$ Institute of Virology, Biomedical Research Center of the Slovak Academy of Sciences, Dúbravská cesta 9, 84505 Bratislava, Slovak Republic
\end{abstract}

\begin{abstract}
Summary. - The aim of this work was to give an overview of murid herpesvirus 4 (MuHV-4) (synonyms: murine gammaherpesvirus 68 , mouse herpesvirus strain 68), the first model for the study of human and animal oncogenic gammaherpesviruses. Based on our results confirming similarity of murine gammaherpesvirus 68 (MHV-68) to another gammaherpesvirus, human oncogenic Epstein-Barr virus (EBV), we were able to interpret some processes observed in the course of MHV-68 infection in analogy to EBV infection. In particular, that were the processes occurring during MHV-68-induced persistent infection in mice accompanied by tumor formation and leukemia following immunosuppression. Since EBV is a highly species specific virus, infecting humans only, these processes cannot be experimentally examined at the molecular, cellular, and tissue levels in natural host. However, they can be investigated in BALB/C mice infected with MHV-68, which is nowadays generally accepted model mainly thanks to experimental results achieved by our research team. The important mouse model MHV-68 is a prototype strain of MuHV-4 species and is classified as a member of the order Herpesvirales, family Herpesviridae, subfamily Gammaherpesvirinae and genus Rhadinovirus. During 40 years since its isolation from wild rodents, the virus was distributed into many virological laboratories in Europe (such as England, Slovakia, Germany, Italy, Portugal, Belgium, Denmark, Spain, Switzerland, Hungary, Russia, Sweden), USA, Canada, China, Korea, Japan and Australia. Global research of this virus, which has become an irreplaceable animal model, has expanded our understanding of the pathogenesis and immunology of human and animal gammaherpesvirus infections as well as the gammaherpesvirus-associated oncogenesis. No less important fact is that MHV-68 provides an excellent model to explore methods for controlling gammaherpesvirus infections through vaccination and chemotherapy.
\end{abstract}

Keywords: MHV-68; EBV; KSHV; immunology; pathogenesis; oncogenesis; genome

\section{Introduction}

In 1976, within a project on isolation of herpesviruses from small rodents in Slovakia, mouse herpesvirus strain

E-mail: virumis@savba.sk; phone: +421905 531222.

Abbreviations: $\mathrm{EBV}=$ Epstein-Barr virus; $\mathrm{KSHV}=$ Kaposi's sarcoma-associated herpesvirus; IAV = influenza A virus; IL = interleukin; IM = infectious mononucleosis, MHV-68 = murine gammaherpesvirus 68; MuHV-4 = murid herpesvirus 4; p.i. = post infection; TLR = Toll-like receptor; $\mathrm{VN}=$ virus neutralization
68 (MHV-68) was isolated (Blaškovič et al., 1980). This virus was accepted by The International Committee on Taxonomy of Viruses (ICTV) as a new, so far unassigned species (member) of the Gammaherpesvirinae subfamily of the Herpesviridae family (Murphy et al.,1995). Electron microscopy structure of new herpesvirus is shown in Fig. 1. Besides MHV-68, another four isolates (MHV-60, MHV-72, MHV-76 and MHV-78) similar to MHV-68 were obtained (Table 1) (Blaškovič et al., 1980). Three more isolates (MHV-Šumava and MHV-4555 and MHV-5682) were later obtained in other field experiments (Mistríková and Blaškovič, 1985, Kožuch et al., 1993). The objective of 


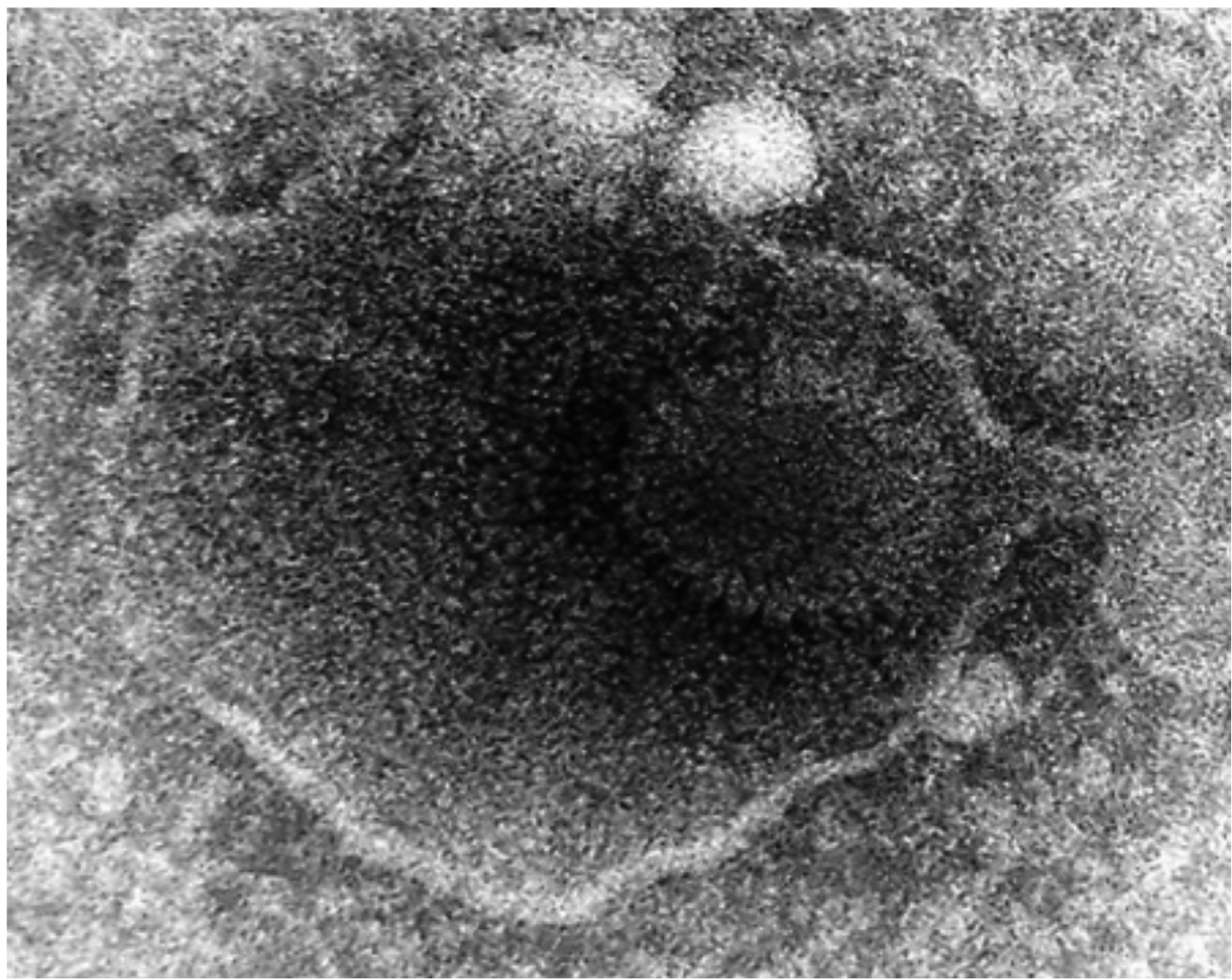

Fig. 1

New herpesvirus isolated from bank vole

Electron microscopy photograph of new herpesvirus isolated from Clethrionomys glareolus done by Fedor Čiampor (1980).

review articles by Mistríková et al. (2000) and by ČipkováJarčušková et al. (2013) was to characterize general properties of the virus with an emphasis on our prior results concerning biology, ecology, epidemiology, pathogenesis, immunology, viral persistence in peritoneal macrophages, detection of malign and benign lymphoproliferation accompanied by the presence of atypical lymphocytes in blood during infectious mononucleosis (IM)-like and leukemia like syndromes. Since its discovery in Slovakia in 1976 (Blaškovič et al., 1980), MHV-68 was distributed to laboratories almost over the whole world. The highest number of publications originated from the laboratories in USA, Great Britain and Slovakia. Important publications have also been produced with the model virus in Germany, China, Korea, Italy, Japan, Portugal, Belgium, Canada, Denmark, Spain, Switzerland, Hungary, Russia, Sweden and Australia (in descending order of the number of publications).

\section{Biological properties of MHV-68}

We characterized biological properties of all isolates of MHV-68 (Svobodová et al., 1982a,b). In contrast to most gammaherpesviruses, MHV-68 forms a fully productive infection in conventional cell monolayer culture. At least twenty cell lines of different origin (rodents, carnivores, birds, pigs, monkey, man) could reproduce five strains of murine herpesvirus (MHV-60, 68, 72, 76, 78) (Svobodová et al., 1982a). Cell lines permissive for growth of all murine gammaherpesvirus isolates are: LB, 293T, NMuMg ,MEF, NIH 3T3, NSO, SP2/0, PM (derived from mouse), RAT (derived from rat), BHK-21 (derived from hamster), $\mathrm{MJ}$ (derived from guinea pig), REF, KrOb, SIRC (derived from rabbit), ZP (derived from hare), CCL-64 (derived from mink), KEB (derived from chicken), PS (derived from swine), VERO, GMK (derived from monkey), LEP, Am-57 (derived from human) (Čipková-Jarčušková et al., 
Table 1. Isolation of murine gammaherpesvirus (MHV) strains

\begin{tabular}{|c|c|c|c|c|c|}
\hline Rodent species & MHV isolate & $\begin{array}{c}\text { Number of passages } \\
\text { in mice resulting } \\
\text { in a virus lethal for } \\
\text { mice }\end{array}$ & $\begin{array}{c}\text { Time required } \\
\text { for onset of clinical } \\
\text { symptoms in mice } \\
\text { (days) }\end{array}$ & $\begin{array}{c}\text { Number of passages } \\
\text { in cell cultures } \\
\text { required to achieve } \\
\text { CPE }\end{array}$ & $\begin{array}{c}\text { Time required for CPE } \\
\text { development in cell } \\
\text { cultures } \\
\text { (days) }\end{array}$ \\
\hline \multirow{3}{*}{$\begin{array}{l}\text { Clethrionomys } \\
\text { glareolus }\end{array}$} & 60 & 3 & 6 & 4 & 5 \\
\hline & 68 & 2 & 6 & 2 & $3-4$ \\
\hline & 72 & 1 & 10 & 4 & 8 \\
\hline \multirow{3}{*}{$\begin{array}{l}\text { Apodemus } \\
\text { flavicollis }\end{array}$} & 76 & 2 & 6 & 1 & 5 \\
\hline & 78 & 2 & 6 & 2 & $3-4$ \\
\hline & Šumava & $\mathrm{ND}$ & ND & 2 & 7 \\
\hline
\end{tabular}

Newborn BALB/c mice were inoculated intracerebrally with a pool of $10 \%$ suspensions from different organs of free-living small rodents. After several brain passages, mice developed severe or fatal encephalitis. Brain suspensions from fatal mouse infections were then passaged in ZP (rabbit lung) cells and BHK-21 (baby hamster kidney) cells. ND = not done; CPE = cytopathic effect.

2013). Furthermore, MHV-68 strain established a persistent infection in mouse myeloma cells and NSO cell line (Sunil-Chandra et al., 1993). Not only mouse B-cell lines (SP2/0 and NSO) were confirmed to be permissive for $\mathrm{MHV}$ (namely for strain 72) in vitro but also mouse T cells from thymus and peritoneal macrophages (Mistríková et al., 1994). Electron microscopy of the cells infected with each of five murine herpesvirus isolates revealed that similar morphological changes were induced displaying characteristic features of developing herpesvirus infection of rabbit embryo cells (REF) (Čiampor et al., 1981). Serological characteristics by complement fixation and virus neutralization (VN) tests confirmed that all five isolates belong to an antigenically identical or very close group (Svobodová et al., 1982a). Antigenic relationship between five isolates of murine gammaherpesvirus were analysed with monoclonal antibodies too (Matušková et al., 2003). Furthermore, we derived the tumor cell line NB78 from BALB/c mice infected with MHV-78 (Mistríková et al., 2006a). In this cell line we demonstrated the influence of hypoxia on reactivation of latent virus infection (Polčicová et al., 2008).

\section{Ecology of MHV-68}

The review article by Wágnerová et al. (2015) is focused on murid rodents as reservoir animals of virus, mechanism of its spread to other animals in the same biotope as well as to livestock and household animals. Prevalence of serum antibodies to MHV-68 was detected in various hosts. Reservoir animals in Slovakia included wood mouse (Apodemus sylvaticus), bank vole (Clethrionomys glareolus), field vole (Microtus agrestis), common vole (Microtus arvalis) and yellow-necked mouse (Apodemus flavicollis) (Blaškovič et al., 1987; Klempa et al., 2001). Non-reservoir wild animals included wild boar (Sus scrofa), red fox (Vulpes vulpes), fallow dear (Dama dama), red dear (Cervus elaphus), European roe deer (Capreolus capreolus), and hare (Lepus europeus). Within the group of farm, domestic and household animals, the hosts were domestic goat (Capra hircus), horse (Equus caballus), cattle (Bos primigenius), domestic dog (Canis lupus familiaris), domestic cat (Felis silvestris catus), and wild house mouse (Mus domesticus) (Wágnerová et al., 2015).

MHV-68 antibodies were also detected in sera of wild host mice (Mus musculus) and in sera of wood mouse (A. sylvaticus) in the UK (Blasdell et al., 2003; Becker et al., 2007). A longitudinal study of antibodies to MHV-68 in bank voles (C.glareolus) and in wood mice (A. sylvaticus) in the UK revealed that seroprevalence was higher in wood mice than bank voles (Telfer et al., 2007).

In 2011, the first molecular detection of MHV-68 in ticks feeding on free-living reptiles was performed (Ficová et al., 2011). MHV-68 was then detected also in Dermacentor reticulatus ticks (Kúdelová et al., 2015), in Haemaphysalis concina ticks (Vrbová et al., 2016) and in adult Ixodes ricinus ticks collected in Slovakia (Kúdelová et al., 2018). The finding of virus in ticks from several separated localities suggested that ticks became infected with MHV-68 via feeding on infected rodents, thus, this virus might be a newfound natural pathogen in ticks. Moreover, the detection of MHV-68 M3 gene transcripts in field-collected ticks suggests that MHV-68 might replicate in their bodies (Hajnická et al., 2017; Kúdelová et al., 2018).

It was recently suggested that bats are another species of animals, which can serve as a reservoir of MHV68. VN antibodies against MHV-68 were detected in four serum samples from the lesser mouse-eared bats (Myotis blythii) and in one sample from the western barbastelle (Barbastella barbastellus). The blood sample with the highest VN antibody titer was found to be MHV-68 positive in nested PCR. In addition, MHV-68 DNA was detected by nested PCR in the case of one 
DNA sample extracted from whole blood collected from the noctule bat (Nyctalus noctula) captured in Kharkiv, Ukraine (Briestenská et al., 2018).

\section{Epidemiology of MHV-68}

We characterized ecological and epidemiological features of MHV-68 in rodents, namely we proved the virus spread through respiratory tract excretes, urine, saliva and tears (Mistríková and Blaškovič, 1985; Kožuch et al., 1993; Mistríková et al., 2000; Hricová and Mistríková, 2008). Moreover, vertical transmission of MHV can occur transplacentally (Štiglincová et al., 2011) or postnatally via breast milk (Hricová and Mistríková, 2008). We also detected antibodies to MHV-68 in human sera. MHV-68specific antibodies were found in laboratory staff working with MHV-68 as well as in the general population (Mistríková et al., 2006b; Hricová and Mistríková, 2007, 2008).

\section{Pathogenesis of MHV-68 infection}

When newborn laboratory mice were inoculated with the isolate MHV- 68 by oral or intranasal routes, the virus spread quickly to the lungs (causing pneumonia), liver, spleen, kidneys, heart muscle, striated muscles, and spinal ganglia (Blaškovič et al., 1984). In juvenile and adult outbred laboratory mice, hematogenic dissemination from the lungs to heart muscle, spleen, liver, thymus, and kidneys has been demonstrated (Rajčáni et al., 1985). Electron microscopy confirmed the replication of MHV within the damaged alveolar septa. Additional studies showed the absence of neural spread even though MHV68 could be recovered from Gasserian ganglia (Rajčáni et al., 1987). These pilot studies showed that MHV was a new herpesvirus.

Primary infection with MHV-68, as with other members of the gammaherpesvirus subfamily, is characterized by a lymphoproliferative phase. MHV-68 causes acute splenomegaly and an IM-like syndrome in which there is expansion of the CD8 ${ }^{+} \mathrm{T}$ cell subset. In long-term infections, MHV-68 is associated with lymphoma development (Sunil-Chandra et al., 1994a; Dutia et al., 1999). During next experiments with mouse model we proved the affinity of all isolates of MHV-68 to B-lymhocytes (Weck et al., 1999a) and peritoneal macrophages (Mistríková et al., 1994; Weck et al., 1999b; Spiššáková et al., 2005). We also demonstrated the role of peritoneal macrophages in chronic infection with MHV-72 as a reservoir of latent virus (Mistríková et al., 1994; Spiššáková et al., 2005). We proved experimental reactivation of latent MHV-72 infec- tion as well as an increased lymphoproliferation following immunosuppression with FK-506 (Mistríková et al., 1996a, 1999). We found oncogenic potential of all isolates of MHV-68 in vivo and in vitro as well (Mistríková et al., 1996b, 2002; Mrmusová-Šupolíková et al., 2003; Pappová et al.,2004; Oda et al.,2005; Mrázová et al.,2015). We observed an IM-like syndrome during acute phase of infection and leukemia-like syndrome during chronic phase of infection with MHV-72 (Mistríková and Mrmusová,1998; Rašlová et al., 2000; Mistríková et al., 2002, 2004). Detection of tumor formation varied in different isolates of prototype strain MHV-68. MHV-60 induced tumor formation in 22\% of infected mice, MHV-68 in 9\%, (Sunil-Chandra et al., 1994a), MHV-72 in 11\%, MHV-78 in 7\% and MHV-Šumava in $14,6 \%$. Unlike previously mentioned oncogenic MHV isolates, MHV-76 did not show any oncogenicity during persistent infection (Mistríková and Rajčáni, 2008).

\section{Immunology of MHV-68}

B-lymphocytes are a major site of virus persistence/ latency (Sunil-Chandra et al., 1992b). The major role in recovery from acute infection have $\mathrm{CD} 8^{+} \mathrm{T}$ cells (Ehtisham et al., 1993). Increase in numbers of B lymphocytes and both $\mathrm{CD}^{+}$and $\mathrm{CD} 8^{+}$lymphocytes cause splenomegaly (Usherwood et al., 1996). Spleen, mediastinal, and cervical lymph node cells from infected mice produced high levels of interleukin 6(IL)-6 and interferon gamma (IFN- $\gamma$ ) and lower levels of IL-2 and IL-10 following in vitro restimulation. These cytokines have potential roles in the establishment and maintenance of persistent infection (Sarawar et al., 1996). On the contrary, the role of IFN- $\gamma$ in the control of acute MHV-68 infection is nonessential or redundant (Sarawar et al., 1997).

MHV-68 is an ideal model system for study of interactions between gammaherpesviruses and their hosts. Intranasal infection of mice with MHV-68 results in replication of the virus in the lung epithelium followed by latent infection of B-cells (Dutia et al.; 1999; Weck et al., 1999a). MHV-68 latency in spleen after intranasal infection is harbored in three types of cells: B-cells, macrophages and dendritic cells (Weck et al., 1999b; Flaño et al., 2000). Following intranasal infection, mice developed an IMlike syndrome accompanied by increased numbers of activated CD8 ${ }^{+} \mathrm{T}$ cells in blood (Hardy et al., 2001). MHV-68 encodes a broad-spectrum chemokine binding protein (M3) (Bridgeman et al., 2001). In acute infection (up to 30 days post infection (p.i.)), the number of $\mathrm{CD}^{+} \mathrm{T}$ cells increased, reaching a maximum at day 11 p.i. This increase correlated with that of $\mathrm{CD} 4^{+} \mathrm{T}$, activated $\mathrm{CD} 19^{+} \mathrm{B}$ cells and natural killer (NK) cells. At day 30 p.i. the numbers of $\mathrm{CD}^{+}, \mathrm{CD}^{+}, \mathrm{CD} 14^{+}$and $\mathrm{CD} 19^{+}$cells decreased to normal 
values. A similar increase in the number of these cells was observed at day 730 p.i. In the course of persistent infection, some of the mice developed leukemia-like syndrome characterized by an increase in the number of leukocytes and appearance of atypical, blastic immature forms of leukocytes (Mrmusová et al., 2002).

In order to understand and possibly treat B-cell malignancies associated with latent gammaherpesvirus infection, it is vital to understand the factors that control the balance between the two transcriptional states of gammaherpesviruses: latency and lytic replication. MHV-68 has been used as a model system to investigate how engagement of endosomal Toll-like receptors (TLRs) impacts reactivation from latency in vitro and establishment of latent infection in vivo. This study revealed that engagement of TLR7 and TLR9 suppresses reactivation of MHV-68 in vitro and that stimulation of TLR7 in vivo increases the frequency of infected cells (Haas et al., 2014). Altogether, MHV-68 provides a unique model for dissecting immunity to large DNA viruses, that persist in B lymphocytes (Doherty et al., 2001).

Analysis of MHV-68 transcription during lytic and latent infection suggests that M3 is an ORF that is expressed early during the establishment of latency in vivo (Simas et al., 1999). It was confirmed that ORF73 gene product encoded by MHV-68 is critical for the establishment and maintenance of latency and for virus persistence in the host (Fowler et al., 2003), while the replication and transcriptional activator (Rta) encoded by ORF50 is essential for lytic replication of MHV-68 and plays an important role in viral reactivation from latency (Wu et al., 2001; Hair et al., 2007).

\section{Genome of MHV-68}

First data concerning murine herpesvirus genome were obtained from partial analysis of MHV DNA strain Šumava (Blaškovič et al., 1988; Blaškovičová, 2007). The first hybridization study by Efstathiou et al. (1990a) demonstrated that the MHV-68 genome had at least 9 ORFs, which were homologous to the sequences of EBV and/or herpesvirus saimiri (HVS). Based on these data, MHV-68 was later on classified in the genus Rhadinovirus, the subfamily Gammaherpesvirinae (Efstathiou et al., 1990b). Genome of this virus was sequenced by Virgin in 1997 (Virgin et al., 1997).

Molecular analyses revealed that MHV-76 genome is essentially identical to that of MHV-68, except for deletion of 9,538 bp at the left end of the unique region. MHV-76 is therefore a deletion mutant that lacks four genes unique to MHV-68 (M1, M2, M3, and M4) as well as the eight viral tRNA-like genes. Replication of MHV-76 in cell culture was identical to that of MHV-68. However, genetic elements at the left end of the unique region of MHV- 68 genome play vital roles in host evasion and are critical to the development of splenic pathology (Macrae et al., 2001). Characterization of a spontaneous 9.5 kilobase-deletion mutant of MHV-68 revealed tissue-specific genetic requirements for latency (Clambey et al., 2002). During latency (until 24 months p.i.), the mice infected with MHV-60, 68, 72, 78 and Šumava developed lymphoproliferative disorders, but MHV-76 was an exception. The lack of tumor formation in MHV-76 infected mice was associated with persistent virus production at late post-infection intervals. While M2 and M3 genes encode immune evasion proteins, M4 codes for a soluble glycopeptide acting as immunomodulator and/or immunostimulator (Gerre et al., 2006; Mistríková and Rajčáni, 2008). Our results showed that oncogenic MHV isolates, as well as MHV-68, have different sets of unique genes at examined area of the genome but they all have M4 gene. In contrast, the only non-oncogenic isolate MHV-76 was lacking shorter or longer portion of M4 gene suggesting absent expression of M4 protein. This may indicate that M4 gene can be in some level, directly or indirectly, involved in oncogenic processes, as hypothesized before (Chalupková et al., 2008). On the other hand, MHV-60 with significantly higher oncogenic potential (22\%) than MHV-68 (9\%) had present identical set of genes (M1-M4) in studied region which may suggest that oncogenic process is most likely driven and facilitated by more than one gene product, as evidenced also during EBV- and KSHV-tumorigenesis. Sequence differences among various virus stocks of isolates MHV-72 and MHV-76 were unexpected, because the primary source of particular isolates was common. While MHV-72 (1997) and MHV-76 (1989) were stored in freezer, MHV-72 (2008) and MHV-76(2008) underwent multiple passages on cell lines from different species. Deleted genes M3-M4 are unique virus-specific genes, identified as nonessential for MHV replication in vitro but playing an important role during pathogenesis in vivo (Evans et al., 2006; Hughes et al., 2011). Therefore, we hypothesize that during long-term viral propagation in cell lines MHV may tend to loose nonessential and for in vitro replication unnecessary genes, to undergo some kind of in vitro virus evolution process. During this action it is possible that the species of origin of cell lines may play a role. Hence it seems reasonable to propagate MHV on the cell lines derived from its natural host and after multiple virus passaging to perform precautionary testing for mutation (Kostrábová et al., 2016). Altogether, through pathogenetic characterization of a deletion mutant MHV-76 we suggested a possible association of the M4 gene with tumorigenic properties of oncogenic MHV isolates (Macrae et al., 2001; Mistríková and Rajčáni, 2008; Chalupková et al., 2008). 


\section{Mouse model for the study of human gammaherpesvirus infection}

The ability of MHV-68 to establish acute and persistent infection within laboratory mice offers a unique opportunity to investigate immunological and virological aspects of gammaherpesvirus pathogenesis (Simas et al., 1998). When MHV-68 is introduced intranasally, the lung is the main tissue infected. Productive MHV-68 infection lasts for around 10 days. During the primary infection, atrophy of thymus and spleen of clinically sick animals can be observed. In contrast, lymphoproliferative responses, typified by splenomegaly, can be seen in asymptomatic animals. These features make MHV-68 a valuable experimental model for investigating the natural gammaherpesvirus infections of man and domestic animals (Sunil-Chandra et al., 1992a). Based on the remarkable biological and genetical similarities with the human gammaherpesviruses, MHV-68 has provided an irreplaceable mouse model for infectious mononucleosis. Further, MHV-68 has proven to be a powerful tool to study the gammaherpesvirus latent infection (Flaño et al., 2002, 2003), the detailed interaction of gammaherpesviruses with its natural host (Nash et al., 1996) and also the host immune response to gammaherpesviruses (Doherty et al., 2001; Woodland et al., 2001; Arico et al., 2002). Equally important is the fact that MHV-68 provides an excellent model to explore methods for controlling gammaherpesvirus infections through vaccination and chemotherapy (Nash et al., 2001; Woodland et al., 2001; Arico et al., 2002). Efforts to develop a KSHV vaccine are limited, but studies with EBV have provided important lessons. Informative vaccine research has been conducted in the mouse infection model of MHV-68, which has generated fundamental principles for an effective vaccination strategy (Wu et al., 2012). The MHV-68 glycoprotein gp150 has significant homology to EBV gp350, which is a candidate vaccine antigen for protection against EBV-related disease. A recombinant vaccinia virus expressing MHV-68 gp150 was used to infect mice. This vaccination resulted in production of MHV-68 neutralising antibodies (Stewart et al., 1999; Gillet et al., 2007a,b). T cell vaccination alters the course of MHV-68 infection and the establishment of viral latency in mice (Liu et al., 1999). Using recombinant MHV-68 is also a highly suitable model to test the immunogenicity and protective capacity of HCV candidate vaccine antigens (El-Gogo et al., 2008). Very important is the use of MHV-68 as immunotoxicological model for examining immunomodulatory drug-associated viral recrudescence (Aligo et al.,2015b). MHV-68 is being evaluated as a model of EBV infection for use in investigation of the effects of immunomodulatory therapy on herpesvirus pathogen- esis in humans (Aligo et al., 2015a). MHV-68 may persist both inside and outside the central nervous system (CNS) once it gains access to the CNS (Kang et al., 2012). Based on similar pathogenetic properties of MHV-68 and EBV, the mouse model is appropriate for the study of human cerebral EBV infection as a hydrocephalus, meningitis, cerebellitis, focal or diffuse encephalitis and temporal lobe encephalitis (Häusler et al.,2005). The MHV-68 model was the first to allow detailed studies on cardiac disease caused by gammaherpesvirus infections and may facilitate the development of more specific treatment options for human cardiac EBV infection (Häusler et al., 2007). An immunosuppressed mouse model of lethal MHV-68 infection is useful for studying potential treatment of EBV infection in man (Smee et al., 1997). The MHV-68 mouse model can help clarify the pathogenesis and immunology of the pulmonary granuloma formation and pulmonary fibrosis and emphysema (Coelho et al., 2006; Zhang et al., 2017). The model of MHV-68 experimental transmission in laboratory mice could help us to better understand the biology of gammaherpesviruses and could also allow the development of strategies that could prevent the spread of gammaherpesviruses in natural populations (François et al., 2013).

Interestingly, recent reports suggested that chronic herpesvirus infection may not only exert harmful effects but may also be beneficial to the host. To further challenge this concept, a mouse strain which spontaneously develops hematological tumors was infected with MHV-68. Using this model, it was observed that infection with MHV-68 completely prevented tumor formation (Raffegerst et al., 2015). Furthermore, MHV-68 can serve as a model for study of dual infection. In order to study the interaction between a gammaherpesvirus and malaria, co-infection model that involves infection of mice with MHV-68 and Plasmodium yoelii non-lethal strain was established. If mice were latently infected with MHV-68 and then coinfected with malaria, significantly less viral load and parasitaemia was observed (Haque et al.,2004). In study of simultaneous infection of mice with MHV-68 and influenza A virus (IAV), we supposed that co-infection with herpes and influenza viruses could be mutually beneficial for the host by promoting its defense against both viruses (Ančicová et al., 2015). Persistent infection with gammaherpesvirus may thus modulate the host immune response to IAV and the acute IAV infection can influence the immune homeostasis established by latent MHV-68 infection (Ančicová et al., 2016). Another study of dual infection (with latent MHV-68 and acute influenza) suggests that costimulatory pathway plays important role in controlling chronic viral infection (Fuse et al., 2007). 


\section{MHV-68 as a model to study the efficacy of antiviral agents}

The first report of an antiviral treatment of MHV-68 infection was published by Sunil-Chandra et al. (1994b). This study demonstrated that acyclovir can be used to minimize the replication of MHV-68 in mice at the site of primary infection, resulting in a reduction in the number of latently infected spleen lymphocytes (Sunil-Chandra et al., 1994b). When evaluated with a model for lethal MHV-68 infections in mice with severe combined immunodeficiency, cidofovir proved to be very efficient in protecting against virus induced mortality (100\% survival at 50 days post infection), whereas acyclovir, brivudine, and adefovir had little or no effect (Neyts and De Clercq, 1998). The antiviral thionucleoside analogue 2'-deoxy5-ethyl-beta-4'-thiouridine (4'-S-EtdU) was shown to be a more potent inhibitor of gammaherpesvirus infection than acyclovir (Barnes et al., 1999). Delta-9 tetrahydrocannabinol (THC) inhibits lytic replication of oncogenic gammaherpesviruses in vitro (Medveczky et al.,2004). A novel nucleoside analogue 1-[(2S,4S-2-(hydroxymethyl)-1,3dioxolan-4-yl]5-vinylpyrimidine-2,4(1H,3H)-dione, or HDVD, was evaluated against a wide variety of herpesviruses and was found to be a highly selective inhibitor of replication of the gammaherpesviruses KSHV, EBV and MHV-68 (Coen et al.,2013). Newly synthesized quinolone/ quinoline derivatives were also tested for their effects on the replication of MHV-68 in vitro. The compound 2-(1-(bD-Xylopyranosyl)-1,2,3-triazol-4-yl)-3,4-dibenzyloxyquinoline showed significant antiviral activity against MHV-68 (Briestenská et al., 2019). Isoprinosine (Inosine acedoben dimepranol) is known as a drug with immunomodulatory and antiviral effects. Positive effect of Isoprinosine on persistent infection of BALB/c mice with MHV-68 was also demonstrated. These results confirmed that each treatment with Isoprinosine should be repeated and must be long-term in some cases of chronic infection (Janíčková et al., 2017).

Some research studies are focused on the study of natural compounds obtained from plants or functional foods in terms of their antiviral activity against gammaherpesviruses. Angular furocoumarin angelicin efficiently inhibited lytic replication of MHV-68 in vitro and chemically-induced lytic replication of human gammaherpresviruses in both EBV- and KSHV-infected cells (Cho et al., 2013). Ginsenosides (Rh2 and Rg3), the major beneficial components in Panax ginseng, can inhibit replication of mouse and human gammaherpesviruses, and thus has the potential to treat gammaherpesvirus infection (Kang et al., 2017, 2018).

One area of growing interest in the field of antiviral therapy is the application of RNA interference for specific inhibition of viral replication. Our research team tested this perspective therapeutic approach in BALB/c mice infected with MHV-68. Mouse siRNA specific to interferon induced transmembrane protein 1(Ifitm1) gene was used to knockdown the expression of Ifitm1 in vivo. It was determined by plaque assay and qPCR that silencing of Ifitm 1 gene expression led to significant inhibition of acute MHV-68 infection in the lungs of BALB/c mice. We demonstrated for the first time a crucial role for IFITM1 in the in vivo infection of gammaherpesviruses. These data also suggest that RNA interference may have therapeutic value in gammaherpesvirus-associated diseases (Hussein et al., 2018).

\section{Summary of most important original results achieved by Slovak research teams:}

- We isolated a novel virus from bank vole (Clethrionomys glareolus). Today, the virus is known as murid herpesvirus 4 or murine gammaherpesvirus strain 68 (MuHV-4 or MHV-68) and it was classified by ICTV in 1995 to the species Murid herpesvirus 4, the genus Rhadinovirus, the subfamily Gammaherpesvirinae, the family Herpesviridae. Besides MHV-68, several similar gammaherpesviruses have been isolated from the same host (MHV-60 and MHV-72) and from yellow-necked mouse (Apodemus flavicollis) (MHV-76, MHV-78 and MHV- Šumava) (Blaškovič et al., 1980; Mistríková et al., 2000).

- We characterized biological properties of all isolates of MHV-68 (Svobodová et al., 1982a,b).

- We proved the affinity of all isolates of MHV-68 to Blymphocytes, T-lymphocytes from thymus and peritoneal macrophages (Mistríková et al., 1994; Spiššáková et al., 2005).

- We demonstrated the role of peritoneal macrophages in chronic infection with MHV-72 as a reservoir of latent virus (Mistríková et al., 1994; Spiššáková et al., 2005).

- We proved experimental reactivation of latent MHV-72 infection as well as an increased lymphoproliferation following immunosuppression with FK-506 (Mistríková et al., 1996a, 1999).

- We described the oncogenic potential of all MHV isolates (except MHV-76) in vivo and in vitro as well (Mistríková et al., 1996b, 2002; Oda et al., 2005; MrmusováŠupolíková et al., 2003; Pappová et al., 2005).

- We observed an IM-like syndrome during acute phase of infection and leukemia-like syndrome during chronic phase of infection with MHV-72 (Mistríková and Mrmusová, 1998; Rašlová et al., 2000; Mistríková et al., 2004).

- We derived the tumor cell line NB-78 from BALB/c mice infected with MHV-78 (Mistríková et al., 2006a). In this 
cell line we demonstrated the influence of hypoxia on reactivation of latent virus infection (Polčicová et al., 2008).

- Through pathogenetic characterization of a deletion mutant MHV-76 we suggested a possible association of the M4 gene with tumorigenic properties of oncogenic MHV isolates (Macrae et al., 2001; Mistríková and Rajčáni, 2008; Chalupková et al., 2008).

- We characterized ecological and epidemiological features of MHV-68 in rodents, namely we proved the virus spread through respiratory tract excretes, urine, saliva, tears, and breast milk, as well as transplacental transmission of the virus during gravidity (Mistríková and Blaškovič, 1985; Kožuch et al., 1993; Mistríková et al., 2000; Hricová and Mistríková, 2008; Štiglincová et al., 2011).

- We detected antibodies to MHV-68 in non-reservoir wild animals, household animals and also in human sera (Mistríková et al., 2000, 2006b; Hricová and Mistríková, 2007, 2008).

- We expanded the number of reservoir host species of MHV- 68 by bats (Briestenská et al.,2018) and confirmed the hypothesis about the possible transmission of MHV-68 in the nature through ticks (Hajnická et al., 2017).

- With the discovery of the new herpesvirus and its initial characterization, we have contributed significantly to the development of a generally accepted model for the study of oncogenic gammaherpesviruses.

Acknowledgments. This work was supported by grant VEGA 1/0617/15 from Scientific Grant Agency of the Ministry of Education of the Slovak Republic and Slovak Academy of Sciences and by grant APVV-17-0445 from Slovak Research and Development Agency.

\section{References}

Aligo J, Brosnan K, Walker M, Emmell E, Mikkelsen SR, Burleson GR, Burleson FG, Volk A, Weinstock D., J. Immunotoxicol. 12, 330-341, 2015a. https://doi.org/10.3109/154769 $\underline{1 X .2014 .980020}$

Aligo J, Walker M, Bugelski P, Weinstock D, J. Immunotoxicol. 12, 1-15, 2015b. https://doi.org/10.3109/154769 $\underline{1 X .2014 .882996}$

Ančicová L, Dugovičová V, Briestenská K, Kostolanský F, Varečková E, Mistríková J., Acta Virol. 60,379-385, 2016. https://doi.org/10.4149/av 201604379

Ančicová L, Wágnerová M, Janulíková J, Chalupková A, Hrabovská Z, Kostolanský F, Varečková E, Mistríková J., Acta Virol.59,369-379,2015. https://doi.org/10.4149/ av_2015_04_369
Arico E, Robertson K, Allen D, Ferrantini M, Belardelli F, Nash AA., J. Interferon Cytokine Res. 22, 1081-1088, 2002. https://doi.org/10.1089/10799900260442502

Barnes A, Dyson H, Sunil-Chandra NP, Collins P, Nash AA., Antivir. Chem. Chemother. 10, 321-326, 1999. https://doi. org/10.1177/095632029901000603

Becker SD, Bennett M, Stewart JP, Hurst JL., Lab. Anim. 41, 229238,2007.https://doi.org/10.1258/002367707780378203

Blasdell K, McCracken C, Morris A, Nash AA, Begon M, Bennett M, Stewart JP., J. Gen. Virol. 84, 111-113, 2003. https:// doi.org/10.1099/vir.0.18731-0

Blaškovič D, Sékeyová Z, Kožuch O, Lysý J, Labuda M, Cupalová A, Mazák V, Vlček M, Chmela J, Hubálek Z, Jirková Z, Janáková K., Biologia 42, 1973-1082 (in Slovak), 1987.

Blaškovič D, Sékeyová Z, Turňa J, Kúdelová M, Slávik I, Mucha V., Acta Virol. 32, 329-333, 1988.

Blaškovič D, Stančeková M, Svobodová J, Mistríková J., Acta Virol. 24, 468, 1980.

Blaškovič D, Staneková D, Rajčáni J., Acta Virol. 28, 225-231, 1984. Blaškovičová J, Tomášková J, Šupolíková M, Mistríková J, Kopáček J., Acta Virol. 51, 143-148, 2007.

Bridgeman A, Stevenson PG, Simas JP, Efstathiou S., J. Exp. Med. 194,301-312,2001.https://doi.org/10.1084/jem.194.3.301

Briestenská K, Janíková M, Kabát $\mathrm{P}$, Csepányiová D, Zukal J, Pikula J, Kováčová V, Linhart P, Band'ouchová $\mathrm{H}$, Mistríková J., Acta Virol. 62, 337-339, 2018. https://doi. org/10.4149/av_2018_229

Briestenská K, Šamšulová V, Poláková M, Mistríková J, Acta Virol. 63, 439-449, 2019. https://doi.org/10.4149/ av 2019411

Chalupková A, Hricová M, Hrabovská Z, Mistríková J., Acta Vet. Brno 77, 231-237, 2008. https://doi.org/10.2754/ avb200877020231

Cho HJ, Jeong SG, Park JE, Han JA, Kang HR, Lee D, Song MJ., Antiviral Res.100,75-83,2013. https://doi.org/10.1016/i. antiviral.2013.07.009

Čiampor F, Stančeková M, Blaškovič D., Acta Virol. 25, 101-107, 1981. https://doi.org/10.1007/BF01301812

Čipková-Jarčušková J, Chalupková A, Hrabovská Z, Wágnerová M, Mistríková J., Acta Virol. 57, 105-112, 2013. https:// doi.org/10.4149/av $2013 \quad 02 \quad 105$

Clambey ET, Virgin HW, Speck SH., J. Virol. 74, 1973-1984, 2002. https://doi.org/10.1128/JVI.74.4.1973-1984.2000

Coelho AL, Weinberg JB, Lira S, Hogaboam CM, Kunkel SL., Sarcoidosis Vasc. Dif. 23, 158-159, 2006.

Coen N, Singh U, Vuyyuru V, Van Den Oord JJ, Balzarini J, Duraffour S, Snoeck R, Cheng YC, Chu CK, Andrei G., J. Virol. 87,3839-3851,2013.https://doi.org/10.1128/JVI.03338-12

Doherty PC, Christensen JP, Belz GT, Stevenson PG, Sangter MY., Philos Trans. R Soc. Lond. B Biol. Sci. 356 581-593, 2001. https://doi.org/10.1098/rstb.2000.0786

Dutia BM, Allen DJ, Dyson H, Nash AA., Virology 261, 173-179, 1999. https://doi.org/10.1006/viro.1999.9834

Efstathiou S, Ho YM, Hall S, Styles CJ, Scott SD, Gompels UA., J. Gen. Virol. 71, 1365-1372, 1990a. https://doi. org/10.1099/0022-1317-71-6-1365 
Efstathiou S, Ho YM, Minson AC., J. Gen. Virol. 71, 1355-1364, 1990b. https://doi.org/10.1099/0022-1317-71-6-1355

Ehtisham S, Sunil-Chandra NP, Nash AA., J. Virol. 67, 5247-5252, 1993. https://doi.org/10.1128/JVI.67.9.5247-5252.1993

El-Gogo S, Staib C, Lasarte JJ, Sutter G, Adler H., J. Gene Med. 10, 177-186, 2008. https://doi.org/10.1002/jgm.1144

Evans AG, Moorman NJ, Willer DO, Speck S., Virology 344, 520531, 2006. https://doi.org/10.1016/j.virol.2005.08.020

Ficová M, Betáková T, Pančík P, Václav R, Prokop P, Halásová Z, Kúdelová M., Microb. Ecol. 62, 862-867, 2011. https:// doi.org/10.1007/s00248-011-9907-7

Flaño E, Husain SM, Sample JT, Woodland DL, Blackman MA., J. Immunol. 165, 1074-1081, 2000. https://doi. org/10.4049/jimmunol.165.2.1074

Flaño E, Kim IJ, Moore J, Woodland DL, Blackman MA., J. Immunol. 170, 3828-3834, 2003. https://doi.org/10.4049/ jimmunol.170.7.3828

Flaño E, Woodland DL, Blackman MA., Immunol. Res. 25, 201-217, 2002. https://doi.org/10.1385/IR:25:3:201

Fowler P, Marques S, Simas JP, Efstathiou S., J. Gen. Virol. 84, 3405-3416, 2003. https://doi.org/10.1099/vir.0.19594-0

François S, Vidick S, Sarlet M, Desmecht D, Drion P, Stevenson PG, Vanderplasschen A, Gillet L., PLoS Pathog. 9, e1003292, 2013. https://doi.org/10.1371/journal. ppat.1003292

Fuse S, Bellfy S, Yagita H, Usherwood EJ., J Immunol. 178, 5227-5236, 2007. https://doi.org/10.4049/jimmunol.178.8.5227

Gerre HM, Ligerwood Y, Templeton KM, Bennet I, Gangadharan B, Rhind SM, Nash AA, Dutia BM., J. Gen. Virol. 87, 803-807, 2006.

Gillet L, May JS, Colaco S, Stevenson PG., PLoS One. 2, e705, 2007a. https://doi.org/10.1371/journal.pone.0000705

Gillet L, May JS, Stevenson PG, Philip G,. PLoS One. 2, e899, 2007b. https://doi.org/10.1371/journal.pone.0000899

Haas F, Yamauchi K, Murat M, Bernasconi M, Yamanaka N, Speck RF, Nadal D., J. Virol. 88, 10002-10012, 2014. https://doi. org/10.1128/JVI.01486-14

Hair JR, Lyons PA, Smith KG, Efstathiou S., J. Gen. Virol. 88,16891697, 2007. https://doi.org/10.1099/vir.0.82548-0

Hajnická V, Kúdelová M, Štibrániová I, Slovák M, Bartíková P, Halásová Z, Pančík P, Belvončíková P, Vrbová M, Holíková V, Hails RS, Nuttall PA., Front Cell. Infect. Microbiol. 7, 458, 2017. https://doi.org/10.3389/fcimb.2017.00458

Haque A, Rachinel N, Quddus MR, Haque S, Kasper LH, Usherwood E., Clin. Exp. Immunol. 138, 396-404, 2004. https://doi.org/10.1111/j.1365-2249.2004.02652.x

Hardy CL, Lu L, Nguyen P, Woodland DL, Williams RW, Blackman MA., Immunogenetics 53, 395-400, 2001. https:// doi.org/10.1007/s002510100341

Häusler M, Sellhaus B, Kleines M., Eur J. Pediatr. 166, 276-276, 2007.

Häusler M, Sellhaus B, Scheithauer S, Engler M, Alberg E, Teubner A, Ritter K, Kleines M., Ann. Neurol. 57, 600-603, 2005. https://doi.org/10.1002/ana.20440

Hricová M, Mistríková J., Acta Virol. 51, 283-287, 2007.

Hricová M, Mistríková J., Biologia 63, 753-755, 2008. https://doi. org/10.2478/s11756-008-0122-z
Hughes DJ, Kipar A, Leeming GH, Bennett E, Howarth D, Cummerson JA, Papoula-Pereira R, Flanagan BF, Sample JT, Stewart JP., PLoS Pathog. 7, e1001321, 2011. https:// doi.org/10.1371/journal.ppat.1001321

Hussein HAM, Briestenska K, Mistrikova J, Akula SM., Sci. Rep. 8, 14105, 2018. https://doi.org/10.1038/s41598018-32350-0

Janíčková O, Ančicová L, Briestenská K, Mistríková J., Acta Virol. 61,32-38, 2017. https://doi.org/10.4149/av 20170132

Kang HR, Cho HJ, Kim S, Song IH, Lee TS, Hwang S, Sun R, Song MJ., Virology 423,23-29, 2012. https://doi.org/10.1016/j. virol.2011.11.012

Kang S, Im K, Kim G, Min H., J Ginseng Res. 41, 496-502, 2017. https://doi.org/10.1016/i.jgr.2016.08.010

Kang S, Song MJ, Min H., J. Funct. Foods. 40, 219-228, 2018. https://doi.org/10.1016/j.jff.2017.11.011

Klempa B, Mačáková K, Labuda M, Kúdelová M., Infect. Dis. Rev. 3, 31-33, 2001.

Kostrábová A, Jarčušková J, Hrabovská Z, Mistríková J., Acta Virol. 60, 111-113, 2016. https://doi.org/10.4149/ av_2016_01_111

Kožuch O, Reichel M, Leššo J, Remeňová A, Labuda M, Lysý J, Mistríková J., Acta Virol. 37, 101-105, 1993.

Kúdelová M, Belvončíková P, Vrbová M, Koval'ová A, Štibrániová I, Kocáková P, Slovák M, Špitalská E, Lapuníková B, Matúšková R, Šupolíková M., Microb. Ecol.70,785-794, 2015. https://doi.org/10.1007/s00248-015-0622-7

Kúdelová M, Slovák M, Kabát P, Derka T, Stevove B, Bohus M, Vrbová M., Acta Virol. 62, 98-103, 2018. https://doi. org/10.4149/av 2018112

Liu LZ, Usherwood EJ, Blackman MA, Woodland DL., J. Virol.73, 9849-9857,1999.https://doi.org/10.1128/JVI.73.12.98499857.1999

Macrae AI, Dutia BM, Milligan S, Brownstein DG, Allen DJ, Mistríková J, Davison AJ, Nash AA, Stewart JP., J. Virol.75, 5315-5327, 2001. https://doi.org/10.1128/JVI.75.11.53155327.2001

Matušková M, Mistríková J, Mrmusová M, Žilka N, Stančeková M, Kontseková E., Arch. Virol. 148, 1027-1036, 2003. https://doi.org/10.1007/s00705-003-0101-1

Medveczky MM, Sherwood TA, Klein TW, Friedman H, Medveczky PG., BMC Medicine 2, 34, 2004. https://doi. org/10.1186/1741-7015-2-34

Mistríková J, Blaškovič D., Acta Virol. 29, 312-317, 1985.

Mistríková J, Blaškovičová J, Pappová M, Hricová M., Acta Virol. 5, 223-228, 2006a.

Mistríková J, Furdíková D, Oravcová I, Rajčáni J., Acta Virol. 40, 41-44, 1996a.

Mistríková J, Hricová M, Šupolíková M., Acta Virol. 50, 69-70, 2006b.

Mistríková J, Moško T, Mrmusová M., Acta Virol. 46, 41-46, 2002. https://doi.org/10.1007/s003940200006

Mistríková J, Mrmusová M., Acta Virol. 42,79-82, 1998. https:// doi.org/10.1086/447483

Mistríková J, Mrmusová M, Ďurmanová V, Rajčáni J., Viral Immunol. 12, 237-247, 1999. https://doi.org/10.1089/ vim.1999.12.237 
Mistríková J, Mrmusová-Šupolíková M, Rajčáni J., Neoplasma 51, 2, 71-76, 2004.

Mistríková J, Rajčáni J., Cent. Eur. J. Biol. 3, 19-30, 2008.

Mistríková J, Rajčáni J, Mrmusová M, Oravcová I., Acta Virol. 40, 297-301, 1996b.

Mistríková J, Rašlová H, Mrmusová M, Kúdelová M, Acta Virol. 44, 211-226, 2000.

Mistríková J, Remeňová A, Leššo J, Stančeková M., Acta Virol. 38, 151-156, 1994.

Mrázová V, Betáková T, Kúdelová M, Šupolíková M, Lachová V, Lapuníková B, Golais F., Intervirology 58, 69-72, 2015. https://doi.org/10.1159/000370071

Mrmusová M, Horváthová M, Klobušická M, Mistríková J., Acta Virol. 46, 19-24, 2002.

Mrmusová-Šupolíková M, Pappová M, Mistríková J., Acta Vet. Brno. 72, 371-376, 2003. https://doi.org/10.2754/ avb200372030371

Murphy FA, Fauquet CM, Bishop DHL, Ghabrial SA, Jarvis AW, Martelli GP, Mayo MA, Summers MD., Virus Taxonomy: Sixth Report of the International Committee on Taxonomy of Viruses. Springer-Verlag, Wien-New York, p. 586, 1995. https://doi.org/10.1007/978-3-7091-6607-9

Nash AA, Dutia BM, Stewart JP, Davison AJ., Philos Trans. R Soc. Lond. B Biol. Sci. 356, 569-579, 2001. https://doi. org $/ 10.1098 /$ rstb.2000.0779

Nash AA, Usherwood EJ, Stewart JP., Semin. Virol. 7, 125-130, 1996. https://doi.org/10.1006/smvy.1996.0016

Neyts J, De Clercq E., Antimicrob Agents Chemother. 42, 170-172, 1998. https://doi.org/10.1128/AAC.42.1.170

Oda W, Mistríková J, Stančeková M, Dutia B, Nash A, Takahata H, Jin Z, Oka T, Hayashi K., Pathol. Int. 55, 558-568, 2005. https://doi.org/10.1111/j.1440-1827.2005.01869.x

Pappová M, Stančeková M, Spiššáková I, Ďurmanová V, Mistríková J., Acta Virol. 48, 91-96, 2004.

Polčicová K, Hrabovská Z, Mistríková J, Tomášková J, Pastorek J, Pastoreková S, Kopáček J., Virus Res. 132, 257-262, 2008. https://doi.org/10.1016/j.virusres.2007.12.004

Raffegerst S, Steer B, Hohloch M, Adler H., Plos One. 10, e0145678, 2015. https://doi.org/10.1371/journal.pone.0145678

Rajčáni J, Blaškovič D, Svobodová J, Čiampor F, Hučková D, Staneková D., Acta Virol. 29, 51-60, 1985.

Rajčáni J, Bustamante de Contreras LR, Svobodová J., Acta Virol. 31, 25-30, 1987.

Rašlová H, Mistríková J, Kúdelová M, Mishal Z, Sarasin A, Blangy D, Berebbi M., Viral Immunol.13,313-327,2000.https:// doi.org/10.1089/08828240050144644

Sarawar SR, Cardin RD, Brooks JW, Merpooya M, HamiltonEaston AM, Mo XY, Doherty PC., J Virol. 71, 3916-3921, 1997. https://doi.org/10.1128/JVI.71.5.3916-3921.1997

Sarawar SR, Cardin RD, Brooks JW, Merpooya M, Tripp RA, Doherty PC., J. Virol. 70, 3264-3268, 1996. https://doi. org/10.1128/JVI.70.5.3264-3268.1996

Simas JP, Efstathiou S., Trends Microbiol. 6, 276-282, 1998. https://doi.org/10.1016/S0966-842X(98)01306-7

Simas JP, Swann D, Bowden R, Efstathiou S., J Gen Virol. 80, 75-82, 1999. https://doi.org/10.1099/0022-1317-80-1-75
Smee DF, Burger RA, Warren RP, Bailey KW, Sidwell RW., Antivir. Chem. Chemother. 8, 573-581, 1997. https://doi. org/10.1177/095632029700800612

Spiššáková I, Vajová K, Mistríková J., Acta Vet. Brno. 74, 425-431, 2005. https://doi.org/10.2754/avb200574030353

Stewart JP., EBV Rep. 6, 31-35, 1999.

Štiglincová V, Chalupková A, Hrabovská Z, Čipková J, Mistríková J., Acta Virol. 55, 55-59, 2011. https://doi.org/10.4149/ av 20110155

Sunil-Chandra NP, Arno J, Fazakerley JK, Nash AA., Am. J. Pathol. 145, 818-826, 1994 a.

Sunil-Chandra NP, Efstathiou S, Arno J, Nash AA., J. Gen. Virol. 73,2347-2356,1992a. https://doi.org/10.1099/0022-1317$\underline{73-9-2347}$

Sunil-Chandra NP, Efstathiou S, Nash AA., Antiviral Chem. Chemother. 5, 290-296, 1994b. https://doi. org/10.1177/095632029400500502

Sunil-Chandra NP, Efstathiou S, Nash AA., J. Gen. Virol. 73, 3275-3279, 1992b. https://doi.org/10.1099/0022-131773-12-3275

Sunil-Chandra NP, Efstathiou S, Nash AA., Virology 193, 825-833, 1993. https://doi.org/10.1006/viro.1993.1191

Svobodová J, Blaškovič D, Mistríková J., Acta Virol. 26, 256-263, 1982a.

Svobodová J, Stančeková M, Blaškovič D, Leššo J, Russ G, Masárová M, Mistríková J., Acta Virol. 26, 438-443, 1982b.

Telfer S, Bennett M, Carslake D, Helyar S, Begon M., J. Wildl. Dis. 43, 32-39, 2007. https://doi.org/10.7589/00903558-43.1.32

Usherwood EJ, Ross AJ, Allen DJ, Nash AA., J. Gen. Virol. 77, 627630, 1996. https://doi.org/10.1099/0022-1317-77-4-627

Virgin HW, Latreille P, Wamsley P, Hallsworth K, Weck KE, Dal Canto AJ, Speck SH., J. Virol. 71, 5894-5904, 1997. https://doi.org/10.1128/JVI.71.8.5894-5904.1997

Vrbová M, Belvončíková $\mathrm{P}$, Koval'ová $\mathrm{A}$, Matúšková $\mathrm{R}$, Slovák $\mathrm{M}$, Kúdelová M., Acta Virol. 60, 426-428, 2016. https://doi. org/10.4149/av_2016_04_426

Wágnerová M, Chalupková A, Hrabovská Z, Ančicová L, Mistríková J., Acta Virol.59, 14-19, 2015. https://doi.org/10.4149/ av_2015_01_14

Weck KE, Kim SS, Virgin HW, Speck SH., J. Virol. 73, 3273-3283, 1999b. https://doi.org/10.1128/JVI.73.4.3273-3283.1999

Weck KE, Kim SS, Virgin HW, Speck SH., J. Virol. 73, 4651-4661, 1999a. https://doi.org/10.1128/JVI.73.6.4651-4661.1999

Woodland DL, Usherwood EJ, Liu LZ, Flaño E, Kim IJ, Blackman MA., Viral Immunol. 14, 217-226, 2001. https://doi. org/10.1089/088282401753266747

Wu TT, Qian J, Ang J, Sun R., Curr. Opin. Virol. 2, 482-488, 2012. https://doi.org/10.1016/i.coviro.2012.06.005

Wu TT, Tong LM, Rickabaugh T, Speck S, Sun R., J Virol. 75, 9262-9273, 2001.https://doi.org/10.1128/JVI.75.19.92629273.2001

Zhang WG, Wu SS, He L, Yang O, Feng YK, Chen YT, Yhen GH, Xu YJ, Yhang YX, Zhao JP., Acta Histochem. 119, 244-251, 2017. https://doi.org/10.1016/i.acthis.2017.01.007 